\title{
Kajian Risiko Penangulangan Tumpahan Minyak: Studi Kasus di Laut Jawa Bagian Barat
}

\section{Oil Spill Mitigation Risk Analysis, A Study Case: Western of Java Sea}

\author{
Andhi Setyonugroho ${ }^{\mathrm{a}}$, Ario Damar ${ }^{\mathrm{b}, \mathrm{c}}$, I Wayan Nurjaya ${ }^{\mathrm{d}}$ \\ ${ }^{a}$ Sekolah Pascasarjana, Institut Pertanian Bogor, Jl. Raya Dramaga Bogor 16680 \\ ${ }^{b}$ Departemen Manajemen Sumberdaya Perairan, Fakultas Perikanan dan Ilmu Kelautan, Institut Pertanian Bogor, Jln. Raya Dramaga \\ Bogor 16680 \\ 'Pusat Kajian Sumberdaya Pesisir dan Lautan (PKSPL), Institut Pertanian Bogor, Jl Raya Pajajaran Bogor 16143. \\ dDepartemen Ilmu dan Teknologi Kelautan, Fakultas Perikanan dan Ilmu Kelautan, Institut Pertanian Bogor, Jl. Raya Dramaga \\ Bogor 16680
}

\section{Article Info:}

Received: 13 - 09 - 2018

Accepted: 29 - 03 - 2019

Keywords:

Bagasse Ashes, Feasibility Production, Silicon.

Corresponding Author:

Andhi Setyonugroho Sekolah Pascasarjana, Institut Pertanian Bogor, Jl. Raya Dramaga Bogor 16680; Email: andhi_setyonugroho@yahoo.co $\mathrm{m}$

\begin{abstract}
Risk of oil spill occured from oil exploration and production in marine should be effectively managed. This research is aim to obtain formula of oil spill risk analysis, risk mapping of oil spill in coastal area, and evaluated risk category in regard to be effectively risk management. The study area cover three coastal regions in western Java sea such as Kepulauan Seribu, Northern Java (Banten, to Karawang coastline) and Eastern Lampung. Oil spill spreading modelling using Mike Zero from three spill sources (Cinta, Krisna and Widuri) resulted potentially impacted coastal by oil spill in certain - 8 months - period (January, February, March, April, May, June, July, and September). Study resulted the ALARP (As Low As Reasonable Practicable) matrix and risk category consist of high, moderate, low and very low category which have range value more than 9.47, 9.46-4.23,4.22 - 3.75, less than 3.74, respectively. Mostly, $77 \%$ of the impacted coastal ecosystem and resource have moderate to high risk. Distribution of risks dominantly occurred in west moonson rather than east moonson. The matrix of division priority of oil spill mitigation based on cumulative risk exposure have high priority during west moonson occured in division 6, 7, 13 and 15 which were impacted to ecosystem of shoreline, mangrove, coral reef, capture fishery, tourism, and sea port area. Meanwhile, during the east moonson, division 2 and 4 have priority to impacted to shoreline, mangrove ecosystem, marine culture, capture fishery and also tourism.
\end{abstract}

How to cite (CSE Style $8^{\text {th }}$ Edition):

Setyonugroho A, Damar A, Nurjaya IW. 2019. Kajian risiko penangulangan tumpahan minyak: studi kasus di Laut Jawa Bagian Barat. JPSL 9(3): 826-839. http://dx.doi.org/10.29244/jps1.9.3.826-839.

\section{PENDAHULUAN}

Salah satu rangkaian dari pengelolaan kawasan perairan yaitu dilakukannya suatu analisa atau kajian risiko atas aktivitas dan berikut dampak potensial ekologi dan keberlangsungannya. Kajian risiko ini sangat penting untuk menentukan tindakan perencanaan dan pengelolaan yang terpadu baik secara teknis dan kelembagaan. Salah satu risiko akibat kegiatan di perairan dan pesisir adalah kejadian tumpahan minyak.

Perairan Kepulauan Seribu, pantai utara Jawa (Banten hingga Karawang) dan pesisir Lampung merupakan wilayah perairan yang penting bagi keberlangsungan ekologi dan kestabilan kegiatan transportasi laut di laut 
Jawa bagian barat terutama ibukota Jakarta. Wilayah ini mempunyai pesisir yang sangat sensitif penting terhadap ekologi dengan keberadaaan Taman Nasional Kepulauan Seribu (TNKs) dan wilayah konservasi mangrove di pesisir Lampung. Wilayah ini juga dilintasi Alur Laut Kepulauan Indonesia (ALKI) dimana kapal-kapal besar dan tanker minyak berlayar. Di sebagian perairan juga terdapat kegiatan migas (minyak dan gas) yang cukup ragam dan tingkat risikonya terhadap potensi kejadian tumpahan minyak.

Mempertimbangkan aspek kepentingan wilayah dan risiko tumpahan minyak yang terjadi, maka diperlukan suatu kajian risiko atas tumpahan minyak di wilayah perairan ini. Kajian risiko meliputi tahapan diidentifikasi risiko, analisa risiko, dan evaluasi risiko (ISO 31000, 2008). Setelah diperoleh suatu kajian risiko dan dampak, maka dapat disusun suatu manajemen tumpahan minyak di perairan. Penelitian ini bertujuan untuk melakukan kajian risiko tumpahan minyak dari kegiatan migas di area studi yang berdampak di pesisir yang meliputi upaya mengembangkan rumusan untuk analisa nilai risiko tumpahan minyak di pesisir wilayah studi dan menentukan nilai risiko tumpahan minyak secara spasial dengan peta risiko serta mengevaluasi nilai risiko di daerah studi dalam upaya pengelolaan risiko yang efektif sebagai masukan kepada pegambil keputusan dalam penanggulangan tumpahan minyak.

\section{METODE PENELITIAN}

\section{Lokasi dan Waktu Penelitian}

Lingkup area penelitian ini dilakukan di laut dan pesisir yang terletak pada provinsi Lampung, Banten dan DKI Jakarta (Gambar 1). Penelitian dilakukan pada bulan November 2017 - Mei 2018.

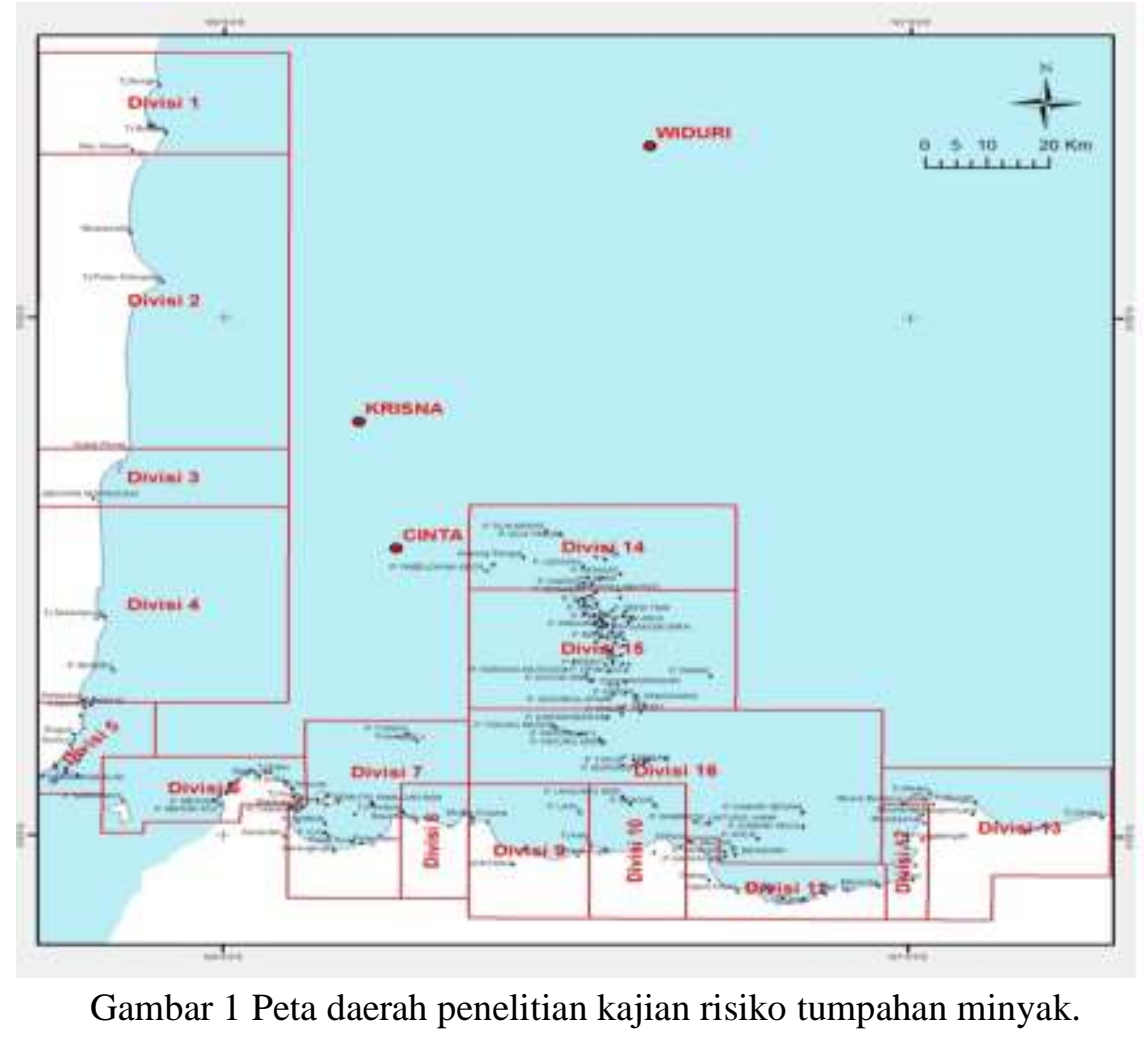

\section{Bahan dan Alat}

Peralatan dan bahan yang digunakan dalam penelitian ini adalah: Peta Indeks Kepekaan Lingkungan (IKL) pesisir Kepulauan Seribu, Lampung Timur, Banten dan DKI Jakarta tahun 2015, Data prediksi pasang surut Pusat Hidrografi dan Oseanografi TNI AL (Pushidrosal) tahun 2017, Peta Pushidrosal kedalaman air laut (batimetri) meliputi Peta No 78. Selat Sunda hingga Tanjung Priok Skala 1: 200000 Edisi Desember 2016, Peta No 414-KK . Pulau-Pulau Seribu : Pulau Jungkung hingga Pulau Peniki Skala 1: 50000 Edisi Desember 2015, Peta No 415-KK . Pulau-Pulau Seribu : Pulau Dua Barat hingga Pulau Tondan Timur Skala 1: 50000 
Edisi Juni 2015. Data pemantauan pasang surut dari Badan Informatika dan Geomatika (BIG) tahun 2016 di stasiun Ciwandan dan Sunda Kelapa, Data pemantauan arus Pusat Penelitian Oseanografi (P2O) Lipi di Pulau Pari pada tahun 2016. Kajian dan peraturan serta pedoman mengenai penanggulangan tumpahan minyak. Perangkat lunak yang digunakan adalah ARC GIS 10.1, Global mapper, Mike zero, Microsoft office.

\section{Metode Pengumpulan dan Analisis Data}

Tahapan proses kajian risiko tumpahan minyak atau Oil Spill Risk Assessment (OSRA) berdasarkan tujuan penelitian mengacu kepada alur proses kajian risiko (ISO 31000, 2008 dan Nissen et al. 2014). Gambar 2 Menjelaskan tahapan dan ruang lingkup penelitian kajian risiko tumpahan minyak.

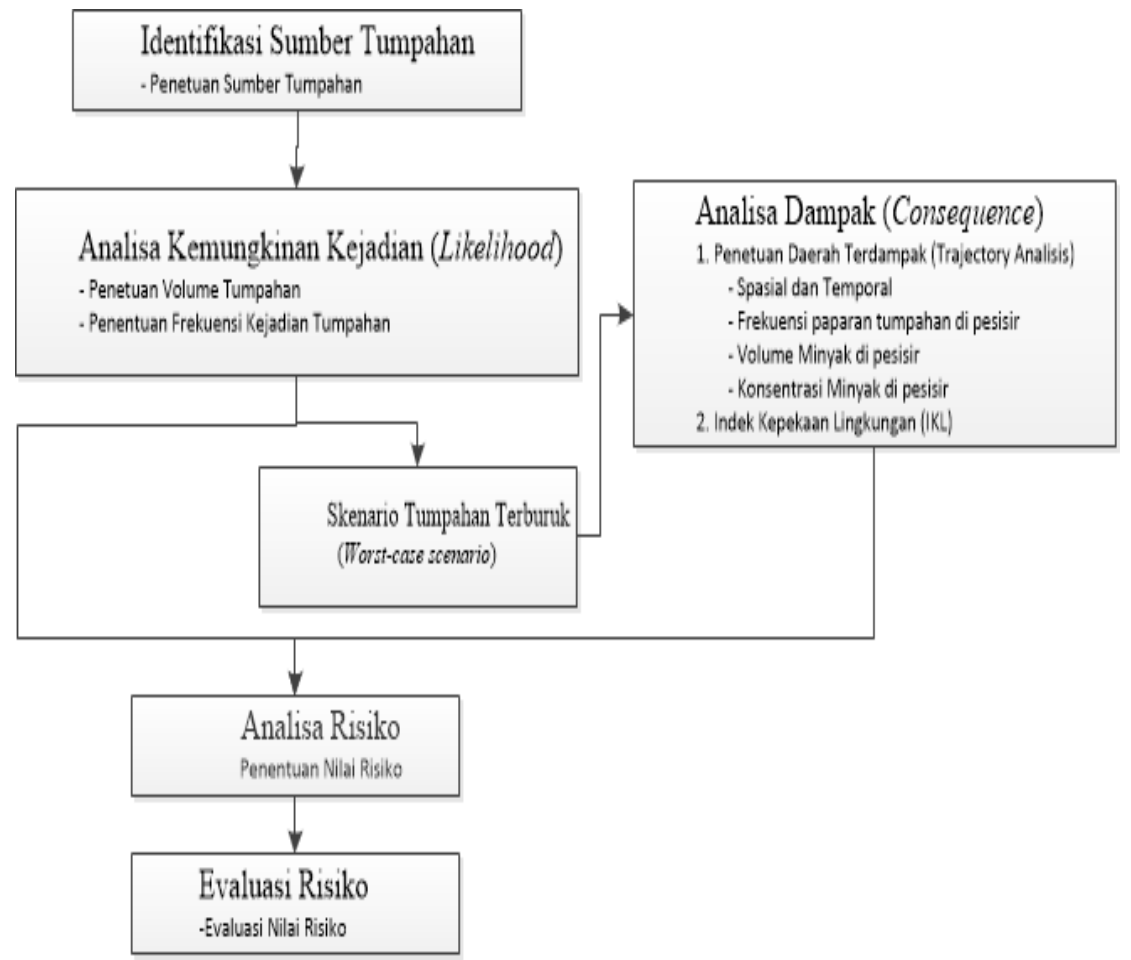

Gambar 2 Diagram ruang lingkup kajian risiko tumpahan minyak.

\section{Penentuan Jenis Sumber, Volume dan Frekeunsi Kejadian Tumpahan Minyak}

Identifikasi sumber tumpahan minyak dalam penelitian ini dibatasi pada sumber pencemar minyak dari kegiatan migas berupa fasilitas dan kegiatan pemboran sumur eksplorasi, anjungan produksi, anjungan proses, pipa penyalur minyak, tanker penampung dan buoy penyalur minyak. Analisa penentuan jumlah volume tumpahan minyak menggunakan pemilihan skenario kejadian terburuk yang memungkinkan (credible worst case scenario). Volume tumpahan minyak pada skenario kejadian terburuk diperoleh dengan cara analisa statistik dengan data seri empiris kejadian tumpahan minyak dan analisa kombinasi teknik serta pendugaan (judgement). Penentuan frekuensi kejadian tumpahan minyak menggunakan pemodelan fungsi distribusi frekuensi terhadap jumlah volume tumpahan (DNV 2011) seperti Tabel 1.

Tabel 1 Distribusi frekuensi kejadian tumpahan minyak pada kegiatan migas (DNV 2011).

\begin{tabular}{cccc}
\hline No & Kegiatan Hulu Migas & $\begin{array}{c}\text { Distribusi Frekuensi } \\
\text { Kejadian Tumpahan }\end{array}$ & Keterangan \\
\hline 1 & $\begin{array}{c}\text { Blowouts pada pemboran } \\
\text { eksplorasi }\end{array}$ & $3.1 \times 10^{-4} \mathrm{Q}^{-0.3}$ & $\mathrm{Q}=\begin{array}{c}\text { Volume Tumpahan } \\
\text { (Ton) }\end{array}$ \\
2 & $\begin{array}{c}\text { Blowouts pada pemboran } \\
\text { pengembangan }\end{array}$ & $2.5 \times 10^{-4} \mathrm{Q}^{-0.3}$ & $\mathrm{Q}=\begin{array}{c}\text { Volume Tumpahan } \\
\text { (Ton) }\end{array}$ \\
\hline
\end{tabular}




\begin{tabular}{cccc}
\hline No & Kegiatan Hulu Migas & $\begin{array}{c}\text { Distribusi Frekuensi } \\
\text { Kejadian Tumpahan }\end{array}$ & Keterangan \\
\hline 3 & Blowouts pada anjungan & $6.9 \times 10^{-5} \mathrm{Q}^{-0.3}$ & $\mathrm{Q}=\begin{array}{c}\text { Volume Tumpahan } \\
\text { produksi }\end{array}$ \\
4 & $\begin{array}{c}\text { Pipan) } \\
\text { Anjungan Proses }\end{array}$ & $2 \times 10^{-5} \mathrm{Q}^{-0.46} \mathrm{~L}$ & $\mathrm{~L}=$ Panjang pipa $(\mathrm{Km})$ \\
6 & $0.019 \mathrm{Q}^{-0.988} \mathrm{P}$ & $\mathrm{P}=\begin{array}{c}\text { Proses produksi (juta ton } \\
\text { per tahun) }\end{array}$ \\
6 & Tanker Penampung & $0.6 \mathrm{Q}^{-05} \mathrm{C}$ & $\mathrm{C}=\begin{array}{c}\text { kapasitas penampung } \\
\text { (juta ton) }\end{array}$ \\
7 & Sarana transfer minyak & $1.1 \times 10^{-3} \mathrm{Q}^{-0.662} \mathrm{~T}$ & $\begin{array}{c}\mathrm{T}=\text { Jumlah transfer per } \\
\text { tahun }\end{array}$ \\
\hline
\end{tabular}

\section{Penentuan Daerah Terdampak Tumpahan Minyak di Pesisir}

Penentuan lokasi daerah terdampak oleh tumpahan minyak memerlukan pemodelan simulasi sebaran tumpahan minyak atau trajektori tumpahan minyak (oil spill trajectory). Perangkat lunak trajektori yang digunakan adalah Mike Zero dengan modul Oil Spill Analysis. Input pemodelan berupa data jenis dan karakteristik minyak mentah, volume dan laju tumpahan, lokasi sumber tumpahan, data angin, hidrodinamika. Hasil pemodelan sebaran tumpahan minyak (trajektori) ini menghasilkan tiga output penting yaitu frekuensi, volume dan konsentrasi tumpahan minyak pada setiap daerah pesisir yang terdampak. Pembatasan pemodelan tumpahan minyak di daerah studi sebagai berikut:

1. Skenario kejadian tumpahan minyak dilakukan secara tunggal yaitu antara skenario kejadian tumpahan dengan skenario tumpahan lainnya bersifat bebas (tidak serentak atau multiple scenario).

2. Jenis tumpahan minyak (oil properties) dari fasilitas migas menggunakan 2 jenis minyak mentah (Sumatra heavy parafinic crude oil) yaitu Cinta dan Widuri. Data spesifikasi jenis minyak diperoleh dari perusahaan migas yang beroperasi di wilayah penelitian Karakteristik minyak ditabulasi di Tabel 2.

3. Periode simulasi pemodelan trajektori setiap skenario dilakukan untuk setiap bulan selama setahun (12 bulan) pada tahun 2016 .

\section{Kepekaan Lingkungan Pesisir terhadap Tumpahan Minyak}

Kepekaan lingkungan pesisir perairan dinyatakan dalam suatu Indek Kepekaan Lingkungan (IKL). Semakin tinggi nilai IKL maka semakin tinggi tingkat kepekaan lingkungan secara ekologis, ekonomis, sosial, dan kesulitan dalam upaya penangulangan tumpahan minyak di daerah terdampak. IKL dibagi 5 kelas yaitu tidak peka (1), kurang peka (2), cukup peka (3), peka (4), sangat peka (5). Studi IKL terdahulu (CNOOC 2015) pada daerah studi digunakan sebagai input dalam penelitian ini. Dalam penelitian kajian risiko tumpahan minyak digunakan 7 ekosistem dan sumberdaya terdampak yaitu: tipe pantai, mangrove, terumbu karang, perikanan tangkap dan budidaya laut, wisata dan pelabuhan. Analisa spasial di area studi dibagi menjadi 16 divisi meliputi pesisir timur Lampung dari Kuala Tulang Bawang sampai Bakauheni, pesisir utara Jawa bagian barat dari Banten sampai Tanjung Sedari Karawang dan Kepulauan Seribu.

Tabel 2 Karakteristik minyak Cinta dan Widuri (Maxus SES 1994).

\begin{tabular}{lcc}
\hline Parameter Minyak & Widuri & Cinta \\
\hline Specific Gravity $\left(15^{\circ} \mathrm{C}\right)$ & 0.8607 & 0.8579 \\
\hline Viskositas Kinematik $(\mathrm{cSt})$ di $140^{\circ} \mathrm{F}\left(60^{\circ} \mathrm{C}\right)$ & 18.06 & 12.37 \\
\hline $82^{\circ} \mathrm{F}\left(28^{\circ} \mathrm{C}\right)$ & Solid & Solid \\
\hline Titik Tuang (Pour Point $)^{\circ} \mathrm{F}\left({ }^{\circ} \mathrm{C}\right)$ & $110\left(43^{\circ} \mathrm{C}\right)$ & $100\left(38^{\circ} \mathrm{C}\right)$ \\
\hline Persentase Kehilangan Berat pada $168 \mathrm{Hrs}(\mathrm{HAVR})$ & 15.4 & 15.1 \\
\hline
\end{tabular}




\begin{tabular}{lcc}
\hline Parameter Minyak & Widuri & Cinta \\
\hline Persentase kelarutan $(\%)$ & 0.0046 & 0.0016 \\
\hline $\begin{array}{l}\text { Fraksi minyak ringan ( berat molekul dibawah } 160 \\
\left.\text { g/mol, menguap dibawah } 300^{\circ} \mathrm{C}\right)\end{array}$ & 0.356 & 0.252 \\
\hline $\begin{array}{l}\text { Fraksi minyak berat ( berat molekul diatas } 160 \mathrm{~g} / \mathrm{mol}, \\
\left.\text { menguap diatas } 300^{\circ} \mathrm{C}\right)\end{array}$ & 0.416 & 0.427 \\
\hline Kandungan Aspal $(\%)$ & 0.05 & 0.05 \\
\hline Kandungan Paraffin $(\%)$ & $21.9-41.32$ & $22.8-26.7$ \\
\hline
\end{tabular}

\section{Penentuan Nilai Risiko Tumpahan Minyak di Pesisir}

Identifikasi dampak tumpahan minyak dikelompokan menjadi tiga dampak, yaitu dampak penanggulangan tumpahan, dampak ekologis dan dampak sosial akibat kompensasi hilang atau rusaknya fungsi sosial (DNV, 2011). Dampak penanggulangan tumpahan direpresentasikan dengan volume tumpahan minyak di pesisir. Dampak ekologis direpresentasikan dengan konsentrasi minyak di pesisir. Dampak sosial direpresentasikan dengan frekuensi paparan minyak di pesisir. Rumus risiko dimodifikasi dari persamaan yang dikembangkan oleh Liu. et al. (2014) dan DNV (2011), sehingga persamaan menjadi:

Dimana;

$$
\text { Risiko }_{i, j, k}=\sum_{i, j, k} P_{, k} \times F_{i, j, k} \times\left\{\left(V_{i, j, k}^{0.72}+f_{i, j, k}\right)+1\right\} \times E_{i}
$$

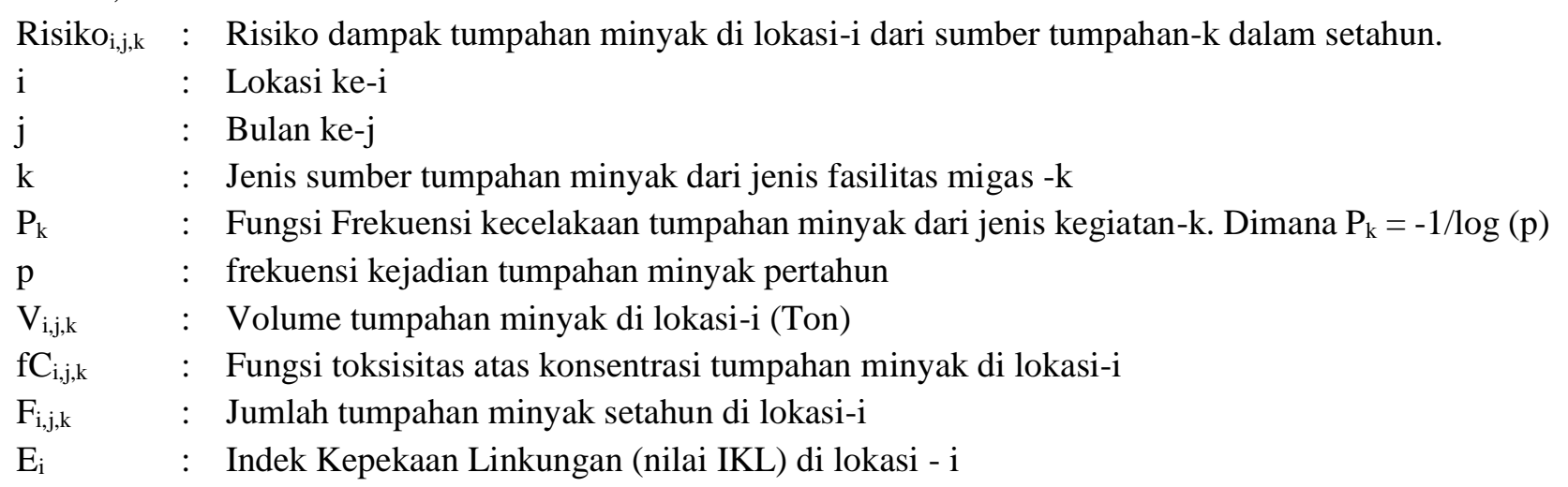

Kajian risiko tumpahan minyak di pesisir dianalisa menggunakan analisa kartografi atau Sistem Informasi Geografis (SIG). Alur diagram penggunaan komponen analisa dirangkai seperti di Gambar 3.

\section{Evaluasi Nilai Risiko}

Identifikasi dampak tumpahan minyak dikelompokan menjadi tiga dampak, yaitu dampak penanggulangan tumpahan, Nilai risiko yang diperoleh perlu dievaluasi dan dikomunikasikan nilai risiko atas kegiatan atau skenario kepada stakeholder dan pembuat keputusan secara logis dan cara yang mudah dipahami untuk memastikan tingkat risiko dapat diterima (tolerable) sehingga keputusan untuk mencapai suatu tingkatan risiko yang dapat diterima atau Acceptable Risk or As Low As Reasonable Practicable - ALARP (Nissen-Lie et al. 2014). Matrik ALARP ini memuat kriteria risiko lingkungan berupa matrik dengan dua variable utama yaitu keparahan (severity) dan frekuensi. Kategori keparahan yaitu volume dan mortalitas di kategorikan pada Tabel 3. 


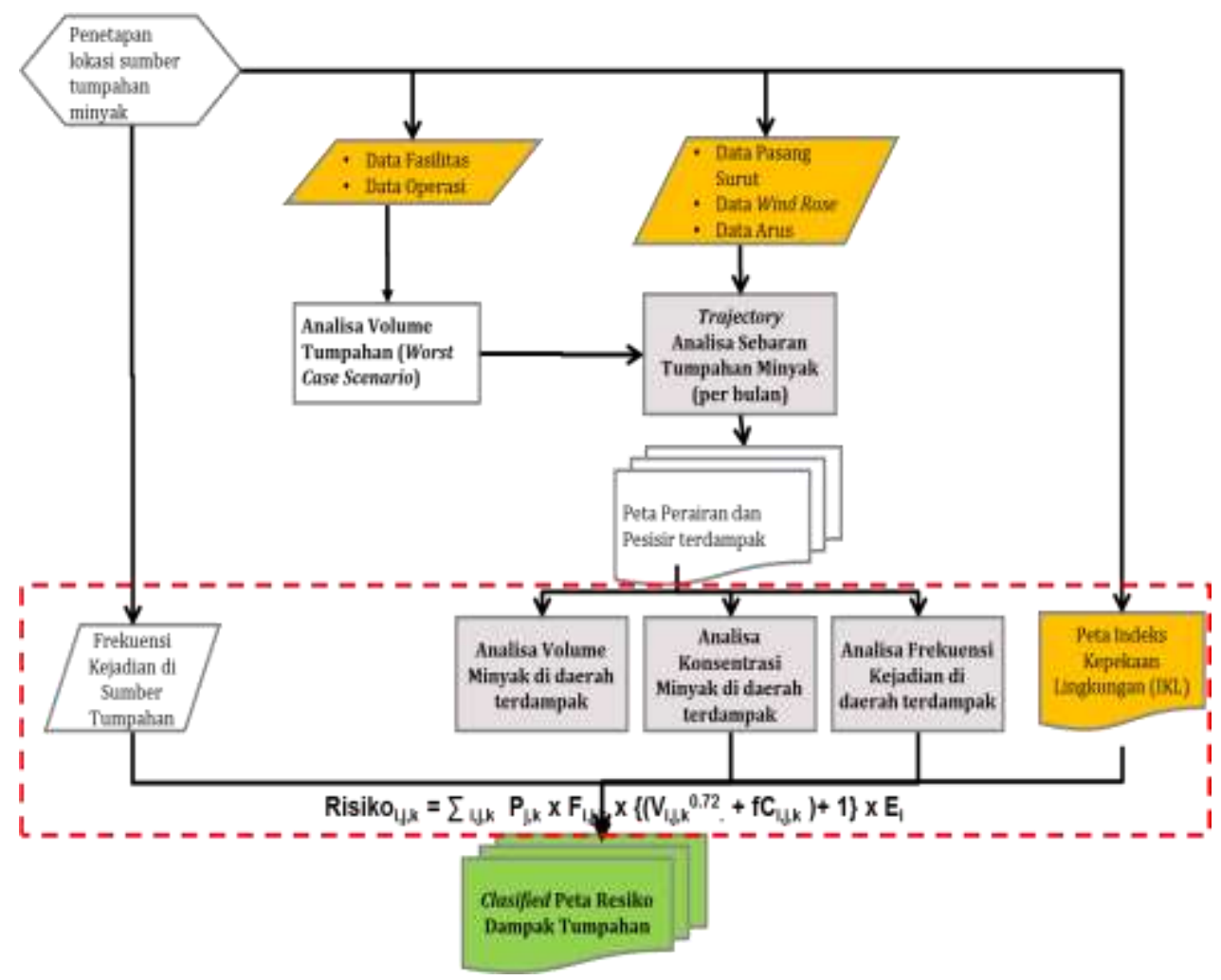

Gambar 3 Diagram alir analisa data pada dampak dan risiko.

Tabel 3 Kategori Frekuensi dan dampak tumpahan minyak.

\begin{tabular}{lrrrr}
\hline Kategori & $\begin{array}{c}\text { Frekuensi Kejadian } \\
\text { Tumpahan (pertahun)* }\end{array}$ & $\begin{array}{c}\text { Kejadian } \\
\text { tumpahan di } \\
\text { pesisir terdampak } \\
\text { (pertahun) }(* * *)\end{array}$ & $\begin{array}{c}\text { Volume Pesisir } \\
(\mathbf{L t r}) * *\end{array}$ & $\begin{array}{c}\text { Mortalitas } \\
(\%)(* * *)\end{array}$ \\
\hline Sangat Kecil & $<0.0001$ & 1 & 20 & 10 \\
\hline Kecil & $0.0001-0,001$ & 2 & 100 & 20 \\
\hline Sedang & $0.001-0.01$ & 3 & 1000 & 40 \\
\hline Besar & $0.01-0.1$ & 6 & 10000 & 60 \\
\hline Sangat Besar & $>0.1$ & 610000 & $>80$
\end{tabular}

Keterangan :*) Kategori Kategori frekuensi kejadian (DNV 2011); **)Kategori volume maksimum tumpahan (Liter) per lokasi tumpahan (CNOOC 2006), ${ }^{* * *}$ )Dikembangkan oleh penulis. Mortalitas $50 \%$ adalah nilai toksisitas pada konsentrasi LC50.

\section{HASIL DAN PEMBAHASAN}

\section{Sumber, Volume dan Frekuensi Kejadian Tumpahan Minyak}

Fasilitas migas di daerah studi terdiri dari 3 area (Business Unit), yaitu Selatan (SBU), Tengah (CBU) dan Utara (NBU). Lokasi sumber tumpahan minyak mewakili setiap area. Hal ini ditujukan untuk mendapatkan perbedaan arah/trajektori penyebaran dan pergerakan tumpahan. Volume yang digunakan mengacu kepada lingkup kajian dan data seri empiris kejadian tumpahan minyak dari fasilitas migas di daerah tersebut. Kelas atau tier volume kejadian yang digunakan sebesar 200 barrel (27 Ton). Nilai frekuensi tertinggi untuk besaran volume di tier 2 berupa jenis fasilitas anjungan proses produksi berkisar antara $2.5 \times 10^{-4}-4.5 \times 10^{-4}$ pertahun (kategori kecil). 


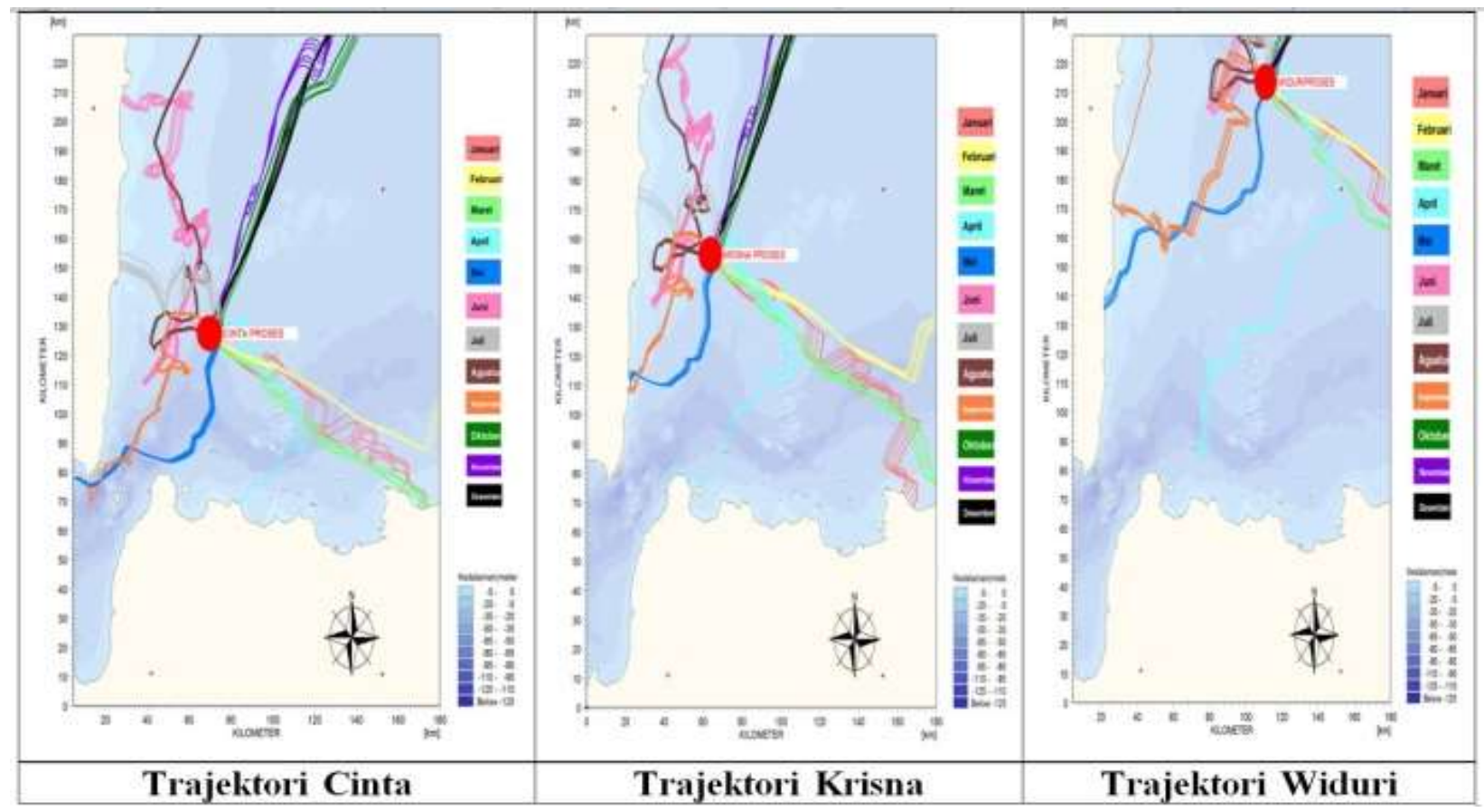

Gambar 4 Hasil trajektori tumpahan minyak.

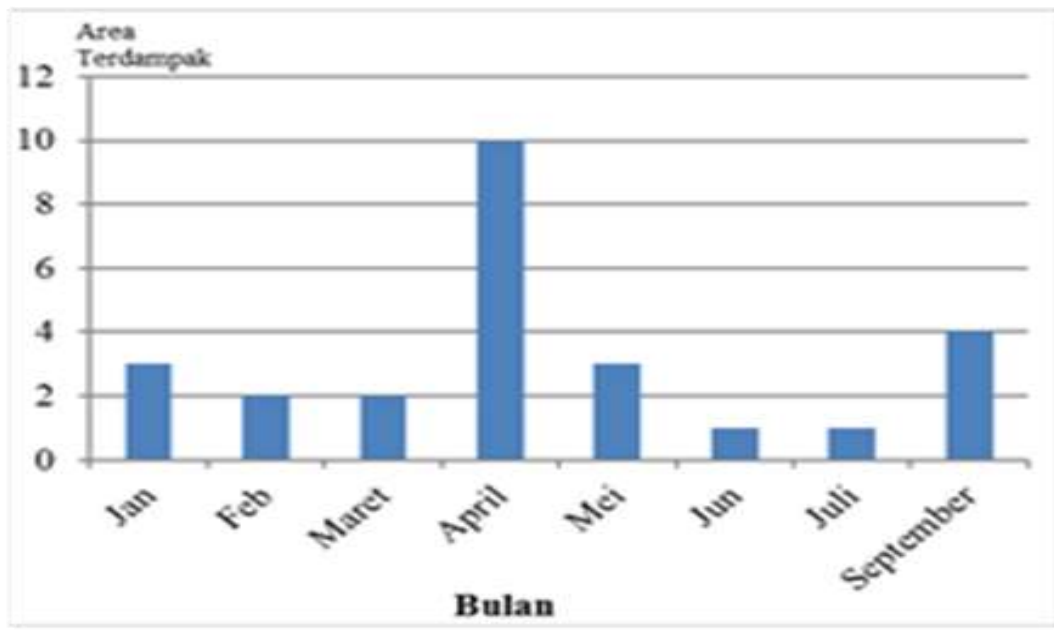

Gambar 5 Distribusi jumlah area terdampak.

\section{Pola Sebaran (Trajektori) Tumpahan Minyak}

Pola sebaran tumpahan minyak (trajektori) dihasilkan dari pemodelan tumpahan minyak menggunakan perangkat lunak Mike Zero. Input pemodelan berupa data jenis dan karakteristik minyak mentah, volume dan laju tumpahan, lokasi sumber tumpahan, data angin, hidrodinamika perairan. Hasil pemodelan dari semua sumber tumpahan (Gambar 4) menunjukan 8 bulan (Januari, Februari, Maret, April, Mei, Juni, Juli, September) berpotensi berdampak kepada ketiga pesisir (Kepulauan Seribu, pesisir utara Jawa (Banten hingga Karawang), dan Pesisir timur Lampung). Empat bulan lainnya menunjukan hasil pemodelan melewati batas wilayah studi. Hasil pemodelan trajektori sumber tumpahan Cinta menunjukan dominan berdampak ke pesisir utara Jawa (Banten hingga Karawang) dan Kepulauan Seribu untuk periode Januari - April (musim barat). Tumpahan minyak berdampak terhadap pesisir Kepulauan Seribu kurang dari 1.5 hari dan 2.5 - 5 hari untuk pesisir utara Jawa (Banten hingga Karawang) sejak waktu tumpahan terjadi. Pada musim timur (Mei sampai Juli) tumpahan minyak berdampak di pesisir timur Lampung dengan waktu berkisar $1-10$ hari. Hasil pemodelan trajektori Krisna menunjukan kesamaan pola seperti sumber tumpahan Cinta yang dominan berdampak ke pesisir utara 832 
Jawa (Banten hingga Karawang) dan Kepulauan Seribu untuk periode Januari sampai April (musim barat). Tumpahan minyak berdampak terhadap pesisir Kepulauan Seribu berkisar 2 - 3 hari dan $4-6$ hari untuk pesisir utara Jawa (Banten hingga Karawang) sejak waktu tumpahan terjadi. Pada musim timur yaitu bulan berpotensi terjadinya dampak, Mei sampai Juli, tumpahan minyak berdampak di pesisir timur Lampung dengan waktu 2 -5 hari sejak terjadinya tumpahan.

Hasil pemodelan menunjukan tumpahan Widuri dominan berdampak ke pesisir timur Lampung dan utara Jawa (Banten hingga Karawang) untuk periode April sampai September (musim timur). Tumpahan minyak berdampak terhadap pesisir timur Lampung berkisar 3-7 hari dan 7 hari untuk pesisir utara Jawa (Banten hingga Karawang) sejak terjadinya tumpahan.

Hasil pemodelan trajektori dari semua sumber tumpahan selama setahun menunjukan 339 Ton tumpahan minyak atau sekitar 34\% (Total 984 Ton tumpahan minyak awal) yang berdampak di pesisir. Berkurangnya jumlah tumpahan minyak dominan disebabkan oleh trajektori atau penyebaran tumpahan minyak keluar dari batas studi dan sedikit disebabkan oleh proses nasib (fate) minyak (penguapan).

\section{Daerah Terdampak Tumpahan Minyak di Pesisir}

Gambar 5 dan Gambar 6 memperlihatkan area terdampak secara kumulatif didominasi (65\% total area) pada bulan Januari sampai April dengan puncak jumlah area terdampak terjadi di bulan April. Pada periode ini area terdampak dipengaruhi oleh musim Barat. Area terdampak meliputi pesisir utara jawa (Banten hingga Karawang) dan Kepulauan Seribu. Jumlah area terdampak terbanyak terjadi pada bulan April yang berdampak dominan di Kepulauan Seribu dan sebagian di pesisir utara Jawa (Banten hingga Karawang). Pada periode bulan Mei hingga September (musim timur) didominasi di pesisir timur Lampung (35\% total area) pada batas studi.

\section{Kategori Nilai}

Matrik ALARP berguna sebagai ilustrasi analisa risiko yang sederhana mengenai hubungan kombinasi antara indikator potensi jumlah tumpahan minyak, indikator sensitivitas dampak dan jumlah frekuensi terpaparnya pesisir terdampak sehingga menghasilkan tingkat dampak. Tingkat dampak kemudian dikombinasikan dengan frekuensi skenario tumpahan minyak yang terjadi dan tingkat kepekaan lingkungan. Frekuensi terpaparnya pesisir terdampak diperoleh dari pemodelan tumpahan minyak. Daerah yang sering terpapar oleh tumpahan minyak mempunyai nilai tinggi dibandingkan dengan daerah yang tidak pernah terkena dampak tumpahan minyak.dengan daerah yang tidak pernah terkena dampak tumpahan minyak.

Gambar 7 menunjukan proses perhitungan kuantitatif nilai risiko dalam upaya menentukan kriteria risiko lingkungan. Rumusan penentuan kriteria risiko mengacu kepada kombinasi rumusan risiko tumpahan minyak di pesisir.

1. Tabel A. Kombinasi nilai pada tingkat keparahan jumlah (volume) tumpahan minyak di pesisir dikombinasikan dengan tingkat mortalitas tumpahan minyak di pesisir serta nilai kriteria frekuensi pesisir terdampak. Hasil tabulasi nilai kemudian di kategorikan menjadi 4 kelas. Dalam tabel warna merah, oranye, kuning dan hijau masing-masing menandakan kelas risiko tinggi, sedang, rendah dan sangat rendah. Penentuan nilai pada batas bawah setiap kelas menggunakan kombinasi kriteria. Nilai kombinasi terkecil terhadap kelasnya digunakan sebagai nilai batas bawah kelas. Dari Tabel A memperlihatkan pada volume tumpahan di kelas yang sama, semakin tinggi nilai mortalitas dan frekuensi terdampaknya pesisir, maka akan semakin tinggi nilai kombinasi komponen resikonya.

2. Tabel B. Kombinasi tingkat frekuensi kejadian tumpahan dari sumber dan tingkat IKL dilakukan secara perkalian mengacu ke rumusan risiko. Penentuan tingkatan batas kelas menggunakan persentil 0.8, 0.6, 0.4 dan 0.2 dari nilai kombinasi dalam Tabel B. Nilai kombinasi terkecil terhadap kelasnya digunakan sebagai nilai batas bawah kelas. 
3. Tabel C. Kombinasi nilai batas bawah kelas dari Tabel A dan Tabel B dilakukan secara perkalian mengacu ke rumusan risiko. Penentuan tingkatan batas kelas menggunakan persentil 0.8, 0.6, 0.4 dan 0.2 dari nilai kombinasi dalam Tabel D. Nilai kombinasi terkecil terhadap kelasnya digunakan sebagai nilai batas bawah kelas atau kategori nilai risiko.

Dalam penelitian ini diperoleh Tabel/matrik ALARP. Nilai batas bawah setiap kelas dari matrik ALARP ini menjadi kelas risiko. Kelas risiko tinggi,sedang, rendah dan sangat rendah merupakan risiko yang masingmasing bernilai lebih dari 9.47, antara 9.46 - 4.23, antara 4.22 - 3.75 dan kurang dari 3.74.

\section{Risiko Ekosistem dan Sumber Daya Alam Terhadap Tumpahan Minyak}

Studi risiko tumpahan minyak yang dikaji meliputi 7 ekosistem dan sumberdaya terdampak yaitu ekosistem pantai, mangrove, terumbu karang, sumberdaya budidaya perikanan, perikanan tangkap, pariwisata, dan pelabuhan laut. Peta risiko ekosistem dan sumberdaya terdampak tumpahan minyak dari semua sumber di wilayah studi disajikan di Gambar 8.

\section{Nilai Risiko Maksimum}

Tabel 4 mentabulasi nilai risiko maksimum pada setiap ekosistem dan sumberdaya di setiap divisi. Pada musim barat, daerah dengan ekosistem dan sumberdaya terdampak di wilayah studi relatif lebih banyak dibandingkan musim timur. Daerah yang terdampak di musim barat (Kepulauan Seribu dan pesisir utara Pulau Jawa) mempunyai sebaran ekosistem dan sumberdaya lebih banyak dibandingkan daerah terdampak pada musim timur (Pesisir timur Lampung). Hal ini menunjukan tumpahan minyak di wilayah studi mempunyai distribusi risiko lebih banyak terhadap ekosistem dan sumberdaya pada musim barat dibandingkan musim timur.

Dalam evaluasi risiko di setiap area di divisi terdampak tumpahan minyak menunjukan sebaran nilai risiko maksimum pada setiap jenis ekosistem dan sumberdaya. Dari Tabel 4 memperlihatkan nilai risiko maksimum terhadap jenis ekosistem dan sumberdaya pada divisi terdampak. Berikut area dalam divisi yang mempunyai nilai risiko maksimum:

\begin{tabular}{|c|c|c|c|c|c|c|}
\hline \multicolumn{2}{|c|}{ TABEL A } & \multicolumn{5}{|c|}{ Kejadian pesisir terkena dampak dalam setahun } \\
\hline Volume & $\begin{array}{c}\text { Dampak } \\
\text { Mortalitas }\end{array}$ & 1 & 2 & 3 & 4 & 6 \\
\hline \multirow{5}{*}{0.054} & 0.1 & 1.15 & 2.31 & 3.46 & 4.61 & 6.92 \\
\hline & 0.2 & 1.25 & 2.51 & 3.76 & 5.01 & 7.52 \\
\hline & 0.4 & 1.45 & 2.91 & 4.36 & 5.81 & 8.72 \\
\hline & 0.6 & 1.65 & 3.31 & 4.96 & 6.61 & 9.92 \\
\hline & 0.8 & 1.85 & 3.71 & 5.56 & 7.41 & 11.12 \\
\hline \multirow{5}{*}{0.171} & 0.1 & 1.27 & 2.54 & 3.81 & 5.08 & 7.63 \\
\hline & 0.2 & 1.37 & 2.74 & 4.11 & 5.48 & 8.23 \\
\hline & 0.4 & 1.57 & 3.14 & 4.71 & 6.28 & 9.43 \\
\hline & 0.6 & 1.77 & 3.54 & 5.31 & 7.08 & 10.63 \\
\hline & 0.8 & 1.97 & 3.94 & 5.91 & 7.88 & 11.83 \\
\hline \multirow{5}{*}{0.897} & 0.1 & 2.00 & 3.99 & 5.99 & 7.99 & 11.98 \\
\hline & 0.2 & 2.10 & 4.19 & 6.29 & 8.39 & 12.58 \\
\hline & 0.4 & 2.30 & 4.59 & 6.89 & 9.19 & 13.78 \\
\hline & 0.6 & 2.50 & 4.99 & 7.49 & 9.99 & 14.98 \\
\hline & 0.8 & 2.70 & 5.39 & 8.09 & 10.79 & 16.18 \\
\hline \multirow{5}{*}{4.708} & 0.1 & 5.81 & 11.62 & 17.42 & 23.23 & 34.85 \\
\hline & 0.2 & 5.91 & 11.82 & 17.72 & 23.63 & 35.45 \\
\hline & 0.4 & 6.11 & 12.22 & 18.32 & 24.43 & 36.65 \\
\hline & 0.6 & 6.31 & 12.62 & 18.92 & 25.23 & 37.85 \\
\hline & 0.8 & 6.51 & 13.02 & 19.52 & 26.03 & 39.05 \\
\hline
\end{tabular}

\begin{tabular}{|c|c|c|c|c|c|c|}
\hline \multicolumn{2}{|c|}{ TABEL B } & \multicolumn{5}{|c|}{ IKL } \\
\hline \multirow{5}{*}{$\begin{array}{l}\text { Frekeunsi } \\
\text { Kejadian } \\
\text { Tumpahan di } \\
\text { pada sumber } \\
\text { (per Tahun) }\end{array}$} & $-1 / \operatorname{LOG}(\mathrm{P})$ & 1 & 2 & 3 & 4 & 5 \\
\hline & 0.25 & 0.25 & 0.50 & 0.75 & 1.00 & 1.25 \\
\hline & 0.33 & 0.33 & 0.67 & 1.00 & 1.33 & 1.67 \\
\hline & 0.50 & 0.50 & 1.00 & 1.50 & 2.00 & 2.50 \\
\hline & 1.00 & 1.00 & 2.00 & 3.00 & 4.00 & 5.00 \\
\hline
\end{tabular}

\begin{tabular}{|c|r|r|r|r|}
\hline \multicolumn{2}{|c|}{ TABEL C } & \multicolumn{3}{c|}{$\begin{array}{c}\text { Kombinasi batas bawah Volume, } \\
\text { Mortalitas dan Frekuensi pesisir }\end{array}$} \\
\hline Kombinasi & & \multicolumn{1}{c|}{ terdampak } \\
\cline { 2 - 6 } batas bawah & & 1.57 & $\mathbf{2 . 5}$ & \multicolumn{1}{c|}{$\mathbf{6 . 3 1}$} \\
\cline { 2 - 6 } Frekeunsi & $\mathbf{0 . 6 7}$ & 1.05 & 1.68 & 4.23 \\
\cline { 2 - 6 } Kejadian dan & 1.57 & 2.50 & 6.31 \\
\cline { 2 - 6 } IKL & $\mathbf{1 . 0 0}$ & 2.36 & 3.75 & $\mathbf{9 . 4 7}$ \\
\cline { 2 - 6 } & $\mathbf{1 . 5 0}$ & 3.93 & 6.25 & $\mathbf{1 5 . 7 8}$ \\
\hline
\end{tabular}

Gambar 7 Kombinasi kriteria risiko. 

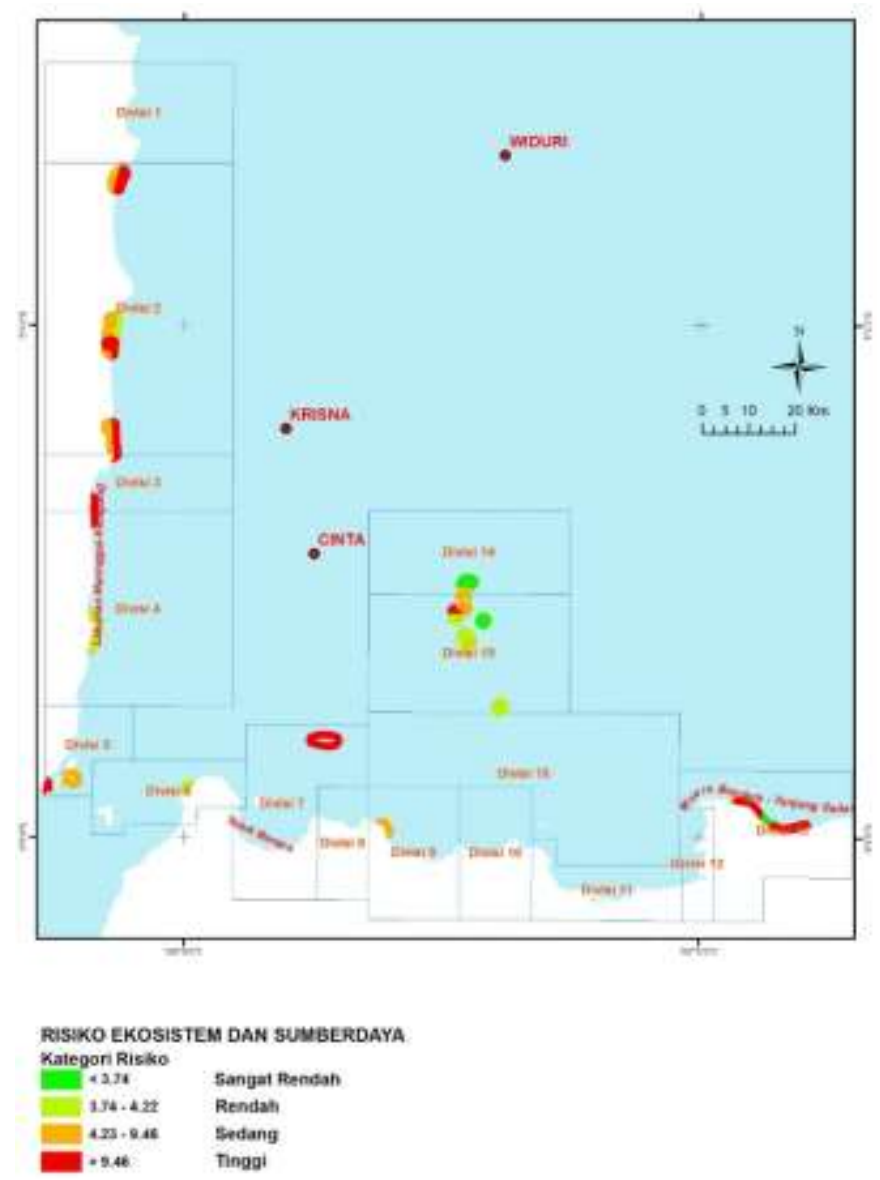

Gambar 8 Peta risiko ekosistem dan sumberdaya di setiap divisi.

a. Ekosistem pantai di Muara Bendera - Tanjung Sedari di divisi 13 pada bulan Januari dan Maret (musim barat). Jenis pantai terdampak di area ini berupa pantai berpasir dengan vegetasi mangrove berkelas IKL peka sepanjang $4.9 \mathrm{Km}$. Pada musim timur terjadi di divisi 4 di pesisir Labuhan Maringgai - Ketapang sepanjang $12.4 \mathrm{Km}$ dengan kelas IKL peka.

b. Ekosistem mangrove pesisir Muara Way Nibung, Pantai Pasir Sakti, Muara Way Sekampung, Pantai Sragi di divisi 4 pada bulan Mei dan September (musim timur). Ekosistem mangrove di area ini berupa kawasan hutan mangrove konservasi daerah Way Sekampung seluas 32.8 Ha dengan kelas IKL cukup peka. Pada musim barat terjadi di Tg. Wetan - Tg. Bungin, Tg. Pakis - Tg. Sedari berupa hutan lindung Cibuaya seluas 7 Ha dengan kelas IKL cukup peka.

c. Ekosistem terumbu karang Pulau Tunda (Teluk Banten) di divisi 7 pada bulan April seluas $81 \mathrm{Ha}$. Terumbu karang di area ini berkategori keragaman sedang dan tutupan karang 49\% serta IKL termasuk cukup peka.

d. Budidaya perikanan di pesisir Labuhan Maringgai - Ketapang seluas 246.5 Ha di divisi 4 pada bulan Mei dan September. Jenis budidaya pada kedua area terdampak merupakan budidaya rumput laut dengan kelas IKL peka.

e. Budidaya perikanan tangkap berada di laut sekitar Labuhan Maranggai - Ketapang di divisi 4 seluas 1754 Ha pada musim timur (bulan Mei dan September). Peralatan tangkap nelayan yang digunakan adalah Sero, bubu kepiting, gillnet tetap/jaring belanak, pukat teri, sondong, seser/sudu, pancing ulur. Pada musim barat di sekitar Pulau Tunda (Teluk Banten) di divisi 7 seluas 2311 Ha pada bulan April. Peralatan tangkap yang digunakan nelayan di area ini antara lain Sero, gillnet tetap/jaring rajungan, trawl 
udang, arad, lampara/dogol, seser/sudu, pancing, jala lempar, dan garuk kerang. Kelas IKL di area ini adalah peka.

f. Pariwisata pada musim barat berada di 2 pesisir yaitu pesisir Muara Bendera - Tanjung Sedari di divisi 13 seluas 41 Ha pada Januari dan Maret dan pesisir Pulau Kelor Barat (Kepulauan Seribu) seluas 56 Ha pada bulan Januari, Februari dan April. Jenis wisata pantai dan diving/snorkling di area Pulau Kelor bernilai IKL peka, sedangkan wisata di Muara Bendera - Tanjung Sedari merupakan wisata pantai berkelas IKL cukup peka. Pariwisata pada musim timur berada di divisi 2 yaitu wisata pantai Way Kambas (Way Seputih - Kuala Penet) seluas 607 Ha bernilai IKL cukup peka pada bulan Juli dan September.

g. Pelabuhan Laut di Kuala Penet - Labuhan Maringgai di divisi 3 seluas 1.5 Ha pada bulan Mei. Jenis pelabuhan laut adalah Tempat Pelelangan Ikan (TPI) berkelas IKL kurang peka.

\section{Nilai Risiko Paparan Maksimum}

Dalam penangulangan tumpahan minyak diperlukan strategi prioritas penanggulangan tumpahan minyak untuk meminimalisasi dampak yang terjadi di suatu ekosistem dan sumberdaya dan meningkatkan efektivitas serta efisiensi penanggulangan. Strategi prioritas adalah menentukan tingkat risiko dan paparan risiko yang terjadi di suatu area ekosistem dan sumberdaya terdampak. Tabel 5 menunjukan besaran nilai risiko paparan kumulatif yaitu besaran kumulatif risiko terhadap luasan area ekosistem dan sumberdaya terdampak tumpahan minyak.

Area ekosistem dan sumberdaya terdampak yang bernilai resiko paparan kumulatif tinggi menjadi prioritas tinggi dalam penanggulangan tumpahan minyak. Hal ini perlu dilakukan mengingat tingkat penggunaan sumberdaya (sarana, prasarana, tenaga kerja, biaya dan waktu) dalam penanggulangan tumpahan minyak terkait dengan nilai resiko paparan kumulatif. Suatu area ekosistem dan sumberdaya terdampak semakin tinggi tingkat risiko paparan kumulatif maka semakin tinggi prioritas penanggulangan sehingga area ini memerlukan perhatian utama. Berikut area-area terdampak tumpahan minyak dengan nilai risiko paparan tertinggi terhadap ekosistem dan sumberdaya:

a. Ekosistem pantai pada musim barat pantai Muara Bendera - Tanjung Sedari di divisi 13 dengan panjang pantai terdampak $53 \mathrm{~km}$ dan Kepulauan Seribu di divisi 15 dengan panjang pantai terdampak $73 \mathrm{Km}$. Pada musim timur terjadi di pantai Way Kambas (Way Seputih - Kuala Penet) - Tanjung Sekopong Penet sepanjang $54 \mathrm{Km}$ di divisi 2 dan pantai Labuhan Maringgai - Ketapang sepanjang $30 \mathrm{Km}$ di divisi 4.

b. Ekosistem mangrove pada musim timur di pesisir Way Kambas (Way Seputih - Kuala Penet) di divisi 2 dengan luas mangrove terdampak seluas $463 \mathrm{Ha}$. Pada musim barat di pesisir Muara Bendera - Tanjung Sedari divisi 13 seluas $81 \mathrm{Ha}$.

c. Ekosistem terumbu karang pada musim barat di Kepulauan Seribu di divisi 14 dan 15 dengan luas terumbu karang terdampak sebesar $840 \mathrm{Ha}$ dan di Pulau Tunda Banten divisi 7 seluas $81 \mathrm{Ha}$.

d. Budidaya perikanan di Labuhan Maringgai - Ketapang di divisi 4 dengan luas budidaya rumput laut sebesar $325 \mathrm{Ha}$.

e. Budidaya perikanan tangkap pada musim barat berada di laut sekitar Pulau Tunda (Teluk Banten) di divisi 7 seluas 2311 Ha dan sekitar divisi 13 seluas 3165 Ha. Pada musim timur budidaya perikanan tangkap berada di laut Way Kambas (Way Seputih - Kuala Penet) di divisi 2 pada musim Timur sebesar 4017 Ha.

f. Pariwisata berada di 2 pesisir yaitu pesisir Way Kambas (Way Seputih - Kuala Penet) di divisi 2 dengan luas wisata pantai terdampak sebesar 5247 Ha pada musim Timur dan wisata pantai (diving dan snorkling) di divisi 14 dan 15 Kepulauan Seribu seluas 1170 Ha pada musim barat.

g. Pelabuhan Laut yang merupakan kawasan industri dan pelabuhan Bojonegoro Banten di divisi 6 pada seluas 45.5 Ha di musim barat. 
Tabel 6. menunjukkan hasil tabulasi ekosistem dan sumberdaya terdampak dari nilai risiko paparan kumulatif tertinggi menjadi suatu matrik prioritas penanggulangan ekosistem dan sumberdaya terdampak tumpahan minyak di setiap musim. Pada musim barat prioritas ditujukan kepada semua komponen ekosistem dan sumberdaya, kecuali budidaya perikanan. Prioritas divisi paling terdampak di musim barat adalah divisi 15 (Kepulaun Seribu) meliputi ekosistem pantai, terumbu karang dan pariwisata pada bulan Januari sampai April. Divisi 13 diprioritaskan kepada ekosistem pantai, mangrove dan perikanan tangkap meliputi pesisir Muara Bendera - Tanjung Sedari Kabupaten Karawang pada bulan Januari dan Maret dan divisi 6 berupa kawasan industri dan pelabuhan Bojonegoro di Provinsi Banten pada bulan April. Divisi 7 meliputi prioritas penanganan ekosistem mangrove dan sumberdaya perikanan tangkap.

Tabel 4 Nilai risiko maksimum area terdampak terhadap ekosistem dan sumberdaya terdampak.

\section{EKOSISTEM DAN SUMBERDAYA}

\begin{tabular}{|c|c|c|c|c|c|c|c|c|c|}
\hline DIVISI & 点 & 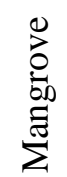 & 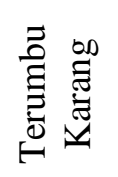 & 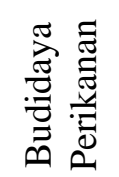 & 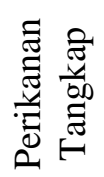 & 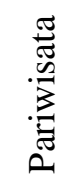 & 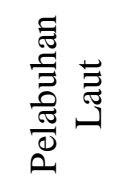 & BULAN TERDAMPAK & MUSIM \\
\hline
\end{tabular}

\begin{tabular}{|c|c|c|c|c|c|c|c|c|c|}
\hline 2 & 19 & 15 & & 15 & 21 & 18 & & Juni, Juli, September & \multirow{4}{*}{ TIMUR } \\
\hline 3 & 15 & & & & 15 & 9 & 7 & Mei, Juli & \\
\hline 4 & 23 & 17 & & 23 & 23 & & & Mei, September & \\
\hline 5 & 14 & 11 & & & 11 & & & September & \\
\hline 6 & 4 & & & & 4 & 4 & 2 & April & \multirow{6}{*}{ BARAT } \\
\hline 7 & 21 & & 15 & & 21 & & & April & \\
\hline 9 & 8 & 5 & & & 5 & & & April & \\
\hline 13 & 29 & 13 & & & 13 & 22 & & Januari, Maret & \\
\hline 14 & 5 & 4 & 4 & & 4 & 5 & & April & \\
\hline 15 & 19 & & 9 & 6 & 14 & 19 & & Januari - April & \\
\hline
\end{tabular}

Tabel 5 Nilai risiko paparan kumulatif divisi pada ekosistem dan sumberdaya terdampak.

\section{EKOSISTEM DAN SUMBERDAYA}

\begin{tabular}{|c|c|c|c|c|c|}
\hline DIVISI & ت & 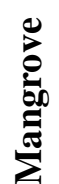 & 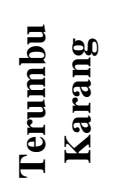 & 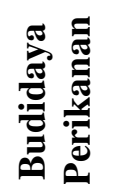 & 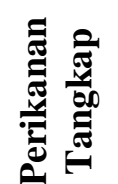 \\
\hline
\end{tabular}

BULAN TERDAMPAK MUSIM

\begin{tabular}{|c|c|c|c|c|c|c|c|c|c|}
\hline 2 & 683 & 6945 & & 459 & 63 & 47210 & & JUNI, JULI, SEPTEMBER & \multirow{4}{*}{ TIMUR } \\
\hline 3 & 193 & & & & 15 & 135 & 13 & MEI, JULI & \\
\hline 4 & 556 & 564 & & 6,832 & 47 & & & MEI, SEPTEMBER & \\
\hline 5 & 231 & 28 & & & 16 & & & SEPTEMBER & \\
\hline 6 & 57 & & & & 2 & 14 & 94 & APRIL & \multirow{6}{*}{ BARAT } \\
\hline 7 & 461 & & 1,253 & & 62 & & & APRIL & \\
\hline 9 & 85 & 124 & & & 5 & & & APRIL & \\
\hline 13 & 931 & 1002 & & & 48 & 1185 & & JANUARI, MARET & \\
\hline 14 & 60 & 3 & 440 & & 4 & 904 & & APRIL & \\
\hline 15 & 867 & & 2780 & 64 & 39 & 6159 & & JANUARI - APRIL & \\
\hline
\end{tabular}


Pada musim timur prioritas ditujukan kepada ekosistem pantai, mangrove, budidaya perikanan, perikanan tangkap dan pariwisata. Prioritas divisi paling terdampak di musim timur adalah divisi 2 yaitu pesisir Way Kambas (Way Seputih - Kuala Penet) meliputi ekosistem pantai, mangrove, perikanan tangkap dan pariwisata pada bulan Juni, Juli dan September. Divisi 4 terdampak pada bulan Mei dan September terhadap ekosistem pantai dan sumberdaya budidaya perikanan berupa rumput laut dan perikanan tangkap terdampak tumpahan minyak.

Tabel 6 Matrik prioritas divisi penanggulangan ekosistem dan sumberdaya terdampak tumpahan minyak.

\section{EKOSISTEM DAN SUMBERDAYA}

BULAN
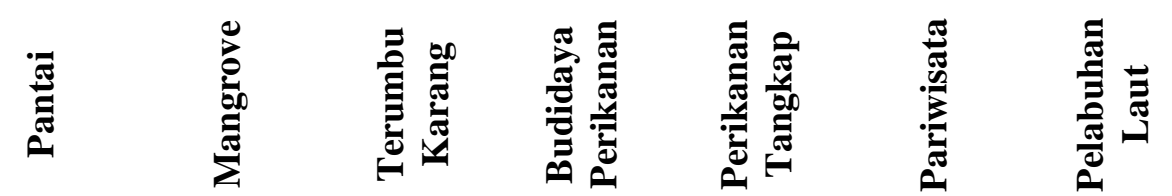

MUSIM

\begin{tabular}{|c|c|c|c|c|c|c|c|c|}
\hline JANUARI & $13 \& 15$ & 13 & \multirow{3}{*}{15} & & 13 & \multirow{3}{*}{15} & & \multirow{3}{*}{ BARAT } \\
\hline FEBRUARI & 15 & & & & & & & \\
\hline MARET & $13 \& 15$ & 13 & & & 13 & & & \\
\hline APRIL & 15 & & $7 \& 15$ & & 7 & & 6 & \\
\hline MEI & 4 & & & 4 & 4 & & & \multirow{6}{*}{ TIMUR } \\
\hline JUNI & 2 & 2 & & & 2 & 2 & & \\
\hline JULI & 2 & 2 & & & 2 & 2 & & \\
\hline AGUSTUS & & & & & & & & \\
\hline SEPTEMBER & $2 \& 4$ & 2 & & 4 & $2 \& 4$ & 2 & & \\
\hline OKTOBER & & & & & & & & \\
\hline NOVEMBER & & & & & & & & \multirow{2}{*}{ BARAT } \\
\hline DESEMBER & & & & & & & & \\
\hline
\end{tabular}

Tabel 7 Cakupan kategori risiko pada ekosistem dan sumberdaya terdampak.

\section{EKOSISTEM DAN SUMBERDAYA}

\begin{tabular}{|c|c|c|c|c|c|c|c|c|}
\hline Risiko & 节 & ๔ِ & $\widehat{\widetilde{E}}$ & 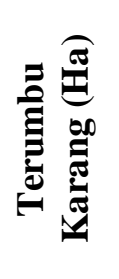 & 胥 & 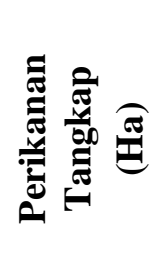 & : & 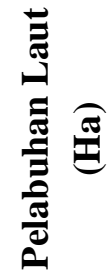 \\
\hline Sangat Rendah & 11 & 1 & & 427 & - & 2706 & - & 46 \\
\hline Rendah & 19 & - & & 315 & - & 3455 & 148 & - \\
\hline Sedang & 104 & 33 & & 99 & 12 & 4908 & 5,630 & 2 \\
\hline Tinggi & 210 & 572 & & 81 & 356 & 11376 & 752 & - \\
\hline Jumlah & 345 & 605 & & 922 & 368 & 22445 & 6,529 & 48 \\
\hline
\end{tabular}

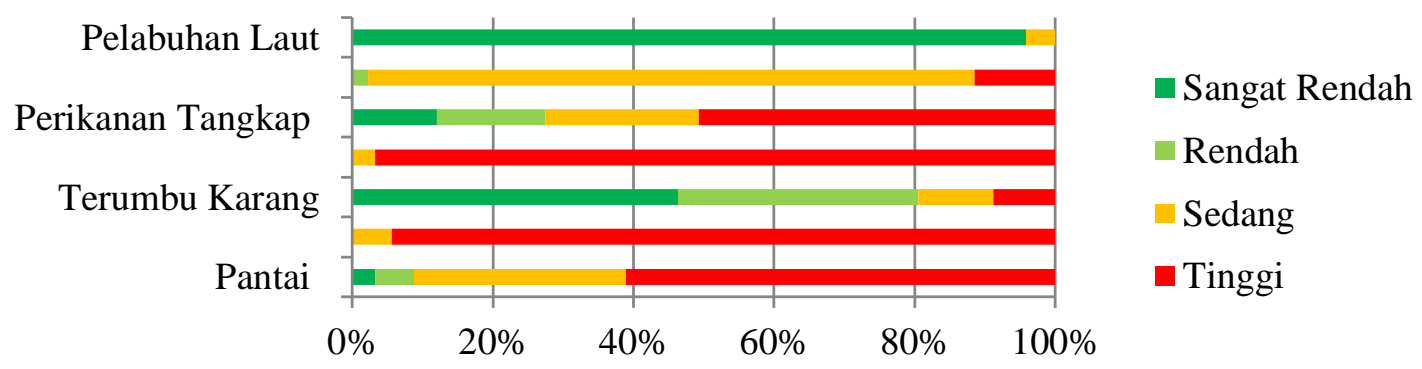

Gambar 9 Persentase tingkat risiko pada ekosistem dan sumberdaya terdampak. 


\section{Cakupan Risiko Ekosistem dan Sumberdaya}

Cakupan kategori risiko pada ekosistem dan sumberdaya terdampak ditabulasi di Tabel 7. Prioritas penanganan ekosistem dan sumberdaya memerlukan pertimbangan cakupan atau area berisiko yang ada. Secara umum, cakupan atau area berisiko berkategori sedang hingga tinggi mendominasi (77\% area beresiko) di area studi penelitian. Prioritas cakupan risiko pada ekosistem dan sumberdaya terdampak berisiko sedang hingga tinggi terjadi berturut-turut yaitu sumberdaya perikanan tangkap, pariwisata, mangrove, budidaya perikanan, pantai, terumbu karang dan pelabuhan laut. Gambar 9. memperlihatkan persentase tingkat risiko pada setiap jenis ekosistem dan sumberdaya terdampak. Jenis ekosistem dan sumberdaya pantai, mangrove, budidaya perikanan, perikanan tangkap dan pariwisata didominasi berisiko sedang hingga tinggi (diatas 70\%). Sedangkan jenis ekosistem terumbu karang dan sumberdaya pelabuhan didominasi risiko rendah hingga sangat rendah (lebih $80 \%$ ).

\section{KESIMPULAN}

Analisa risiko tumpahan minyak di pesisir terdampak di wilayah studi menggunakan kombinasi dari 5 faktor penentu dalam perumusan nilai risiko yang efektif yaitu frekuensi terjadinya tumpahan minyak di sumber tumpahan $(\mathrm{P})$, volume atau masa minyak yang mencemari pesisir terdampak $(\mathrm{V})$, frekuensi kejadian pencemaran di pesisir $(\mathrm{F})$, persentase mortalitas terhadap toksisitas jenis minyak $(\mathrm{Fc})$ dan nilai IKL $(\mathrm{E})$ di pesisir terdampak. Nilai risiko yang dihasilkan dikategorikan menurut kelas atau tingkat risiko yaitu tinggi, sedang, rendah dan sangat rendah. Peta risiko tumpahan minyak di pesisir diperoleh melalui analisa spasial berdasarkan nilai dan tingkat resikonya. Ekosistem dan sumberdaya pesisir terdampak di daerah penelitian mempunyai sebaran risiko didominasi berkategori sedang hingga tinggi. Prioritas penanggulangan risiko tumpahan minyak diperoleh dengan memprioritaskan ekosistem dan sumberdaya pesisir terdampak berkategori risiko paparan kumulatif tinggi. Ekosistem dan sumberdaya pesisir berisiko sedang hingga tinggi rentan terjadi di Kepulauan Seribu dan pesisir utara Jawa (Pulau Tunda Banten dan Kabupaten Karawang) pada musim barat, sebaliknya pada musim timur terjadi di pesisir timur Lampung.

Model atau formulasi analisa risiko tumpahan minyak di penelitian ini pada masa mendatang perlu diuji kesesuaian pada wilayah dan sumber tumpahan yang memiliki karakteristik yang berbeda (IKL, hidrodinamika, meteorologi dan jenis minyak) untuk mendapatkan pengembangan perumusan risiko yang lebih baik.

\section{DAFTAR PUSTAKA}

[CNOOC] China National Offshore Company. 2006. Procedure for Preparation and Operation of Risk Control Measures and Safe Systems of Work. HSEGP-010-2001. Revision 3. Jakarta Indonesia.

[CNOOC] China National Offshore Company. 2015. Indeks Kepekaan Lingkungan. Kawasan Pesisir Lampung Bagian Timur, Pesisir Utara Jawa Bagian Barat, dan Kepulauan Seribu.

[DNV] Det Norske Veritas. 2011. Final Report Assessment of the Risk of Pollution from Marine Oil Spills in Australian Ports and Waters. Report No PP002916. London. United Kingdom.

[IPIECA] International Petroleum Industry Environmental Conservation Association. 2000. A Guide To Contingency Planning For Oil Spill On Water. Edisi kedua. Volume 2. London. United Kingdom.

[ISO] International Organization for Standarization 31000. 2008. Risk Management. Geneva

[Maxus SES] Maxus Southeast Sumatera. 1994. Environmental Study on Sensitivity and Characteristic of Crude Oils Laboratory Studies (ESACOC). Jakarta.

Liu X, Meng R, Xing Q, Lou M, Chao H, dan Bing L. 2014. Assessing oil spill risk in the Chinese Bohai Sea: A case study for both ship and platform related oil spills. Ocean and Coastal Management. 108: 140146.

Nissen-Lie TR, Brude OW, Aspholm OO, Taylor PM, dan Davidson D. 2014. Developing a Guideline for Oil Spill Risk Assessment and Response Planning for Offshore Instalations. International Oil Spill Conference. 